ワークショップ2 :

\title{
オーダリングならびに病院医療情報システムに おける問題点と炎の解決
}

1.オーダリング導入計画進行中の当院の取り組みと炎の問題点

一秋田県厚生連 9 病院同時進行一

秋田組合総合病院：坂 本 哲 也

2.オーダリングならびに病院医療情報システムにおける問題点と光の解決

3 . 電子カルテ稼動後の問題点及び农の対策

土浦協同病院 : 酒 井 義 法

安城更生病院: 横 井武

4 . 現行オーダリングシステムから学ぶ氵電子カルテ導入に向けての検討

5 .いわゆる電子カルテを導入して

鈴鹿中央総合病院：稲 垣 憲 -

JA 高知病院: 中 山 拓 郎

司会 土浦協同病院 : 真 田 勝 弘

鈴鹿中央総合病院 : 浜 田 正 行

は じめに

病院業務のIT 化は, 好むと好まざるとにか かわらず時代の要請であり, 本学会に所属する 各施設においてもさまざまな形で取り組まれて いる。医療情報システムは, 医事業務, 検査・ 処方オーダーなどのオーダリングシステムか ら，部門統合の情報システムへ，さらには電子 カルテシステムへと発展してきた。乥してシス テムネットワークは施設内から施設間, 地域内 へと範囲が拡がり，医療情報を共有することに より質の高い, 効率的な医療が患者に提供され る事になる。病院医療情報システムは, 地域医 療連携のための必須のツールとして，今後ます ます極めて速いスピードで進化するものと思わ れる。

本ワークショップでは, 種々の発展段階のシ ステムを既に使用しているところから, 現在構 築を目指しているところまでの 5 施設の演者か ら, 現状と問題点, 解決策を発表していただ
き，今後への指針にしたい。

\section{各演者の講演概要}

坂本 (秋田組合総合病院) : 秋田県厚生連 9 病院が同時進行で，医療情報ネットワークシス テム構築に向け取り組んでいる。共通のシステ 么構筑を同時に行なうことにより，9病院が情 報を共有できること，導入のスケールメリット が大きいこと，これからのDPC，会計準則へ の対応に向け必要なことなどを挙げ, 現在「情 報ネットワークシステム委員会」と谷のワーキ ンググループが立ち上げられ，精力的に活動し ていることを発表した。

酒井 (土浦協同病院) : 1 ,000余床の大規模病 院で, 350台のクライアントを擁する規模の新 システムを, 約半年間で導入・開始し, 兴の後 成功裏に運用している実績を報告した。開発に 要した期間を圧縮し経費を節減できたのは，院 内業務の編成から要件定義書の作成までを筑波 大学電子工学系の専門家のアドバイスを得て， 
全て病院主導で作り上げたこと，運用開始後の 保守管理も職員が行ない, リモートによるバッ クアップのみを業者に任せるという保守管理体 制が，管理費用の圧縮につながっていると述べ た。

また本システムの特徵は, web application を利用してシステム本体に負担をかけることな く容易に必要な機能を追加できること, システ ム導入前のデータを end user computing とい う考え方に基づいて抽出できることなど多くの 利点，工夫がなされている事である。

横井 (安城更生病院) : 平成14年 4 月30日の 新築移転と同時に始まった電子カルテシステム の稼動 2 年半後の現状と問題点を述べた。この 発表ではシステム障害を, サーバー基幹ネット ワークのハード故障 , プログラム修正後に起き る予期せぬ不具合，潜在的なソフトの不具合， 人為的ミスに分類して, これらの障害が患者に 及ぼす影響度を $\mathrm{A} \sim \mathrm{C}$ にランク分けして障害の 実態を分析した。

ソフトの不具合は初期の頃に比へ，使い込ん でいるうちに減少してきたのに対して，ハード の故障は通常 4,5 年 6,7 年くらいで生じ るといわれているにもかかわらず, 電子カルテ のように24時間，365日稼動していれば2年く らいで起きてくるだろうとのことであった。

障害発生の部署別頻度は, 電子カルテシステ ムと看護システムで50\%を占め, 画像・放射 線, 検査, 医事会計, ネットワークの各システ ムの順になっているとのことであった。障害発 生時, 直ちに職員に通知するために, 光 (ライ ト）または音で知らせる方法を検討していると のことである。

今後の取り組むべき課題として地域連携シス テムの構築, データの後利用, レセプト電子化 なども展望した発表であった。

稲垣（鈴鹿中央総合病院）：平成 5 年の新築 移転時から導入した外来診療支援, 病棟診療支 援および看護支援の3つから成るオーダリング システムの立ち上げ時と, 外来での再来予約機 の設置時を含むハードウェア・OS 等のバー ジョンアップに際しての苦労, 問題を具体的に
挙げた。外来予約ソフトは患者が使いやすいよ うに患者本位の精神を尊重すること，またオー ダリングソフトは目的, 使いやすさ, 機能の追 加など，管理職の強力なリーダーシップの下， 院内全体のコンセンサスが必要であると振り 返った。また全体の経費削減の面からも保守 . メンテナンス契約は当初から予算化すべきであ ると述べた。

中山 (JA 高知病院): 平成14年 4月 1日の 新筑移転と同時にオーダリングシステムが, 光 して同年 7 月 1 日から電子カルテが稼動した。 2 年間の経験から, 外来診療がピークに達する 10時過ぎからコンピューターの動作環境が悪く なる，「医師は画面ばかり見て患者の顔を見な い」等のクレームが出る, 看護師や医事課職員 の仕事は簡素化されたが医師の仕事は増えた， など問題点を述べた。また入院診療におけるク リニカルパスの運用も電子カルテに組み込んで 行こうと考えているとのことであった。

討論とまとめ

演者施設の機種の内訳は, 電子カルテは安城 更生病院と JA 高知病院, オーダリングシステ ムは11年前に稼動し始めた鈴鹿中央総合病院と 1 年半前からすばらしいシステムが稼動した土 浦協同病院，兰れに現在計画・構筑中の秋田組 合総合病院からの発表で, 医療情報システムの 導入，運用における問題点が浮き彫りにされた が, 討論では開発から運用の過程を, 計画, 構 築，運用，保守管理に細分して討論した。 計画段階における留意点

院長以下病院管理者の強いリーダーシップが 必要な事は論を待たない。また委員会組織の構 成メンバーは病院医療の業務に精通したものが 先ず必要で, コンピューターに堪能なだけでは 医療現場の計画に問題があり，理想的には光の 双方のセンスを兼ね備えた人が最適であるとの 結論であった。機種の選定も，メーカーの押し 付けではなく，あくまでも現場主導で必要な ニーズに応答可能な仕樣を提供できるメーカー や機種を選定すべきであるというのが大方の意 見であった。 
システム (ソフト) の構築

既存, 現有の装置, 例えば医事課システム， 検査・処方オーダリングシステムなどを廃棄せ ずに使えれば経費が節約でき，さらに蓄積され た過去のデータを新しいシステムに移行できる ソフトが構築できれば望ましい。機種選定に当 たっては, 各部署の業務を網羅した院内の要望 書を作り, 弚れに対してメーカーが提案書を出 してソフトを構築する手法になる。ソフトは当 初, シンプルなものから出発し, 将来発生する ニーズに合わせ発展性のあるものを選ぶべきで あろう。

初期構築とランニングに要する経費

医療収入の $3 \%$ 以内というのが一般的だ光う だが，1\%以内に納まっているところから，20 年返済で初期コストとランニングコストを合わ せて20億のところまで, 樣々であった。電子力 ルテにしろ, オーダリングシステムにしろ , 構 築と運用には多額の経費を要する。今回発表の 施設の中には電子工学の専門家のアドバイスを 得て, 病院主導のソフトを構築し素晴らしいシ ステムを比較的廉価で導入できたところもある が，これはむしろ例外的な事例と考えるべきで あろう。医業収益の伸びが期待できない現行医 療制度のなか, 厳しい出費であってもシステム 導入に取り組まざるを得ない現実がある。

運用開始に当たって

医師をはじめ職員に対する訓練は, システム 稼動を円滑に進めるために大変重要であるが, 医師の場合，安城では12時間でクリアでき，約 1 か月経つと患者の顔を見ないというクレーム も徐々に減ってきた。どこの施設も導入当初は
混乱を伴うが，機器の操作に慣れることで， 1 か月もすれば外来の混乱, 待ち時間も解消され るということである。患者さんと地域の人々に 対する周知も早い段階から院内揭示产の他の情 報手段で案内することでクリアできたとのこと であった。

セキュリティーの問題

個人情報の保護, いわゆる情報のセキュリ ティーの問題は, 業務の IT 化に際して重要な 問題であるが, 外部からの不正アクセス , ウイ ルス感染に関しては外部ネットワークからの遮 断により防止できる。内部からのアクセスにつ いては個人のパスワードの設定や，アクセスし たときの警告の発信など工夫が必要となる。

$$
\text { おわりに }
$$

医療情報システムは今後電子カルテに進むこ とは間違いないが , 最初に電子カルテありきで はなく，あくまでも病院医療情報ネットワーク が必要なのであり，1人の患者さんの診療計 画，ひいてはクリニカルパスの設定による医療 の標準化, 光して効率的医療の遂行のためのひ とつのツールとして , 今後電子カルテを構築 し，また運用していくことが肝要であるとの共 通理念のもとにいろんな角度から論じていただ いた。

ご発表いただいた演者の皆さんと, 活発な討 論に加わっていただいた会場の皆樣に感謝の意 を表したい。このワークショップの成果がこれ からの医療情報システム構筑を目指す会員諸氏 に少しでもお役に立っていただければと願うも のである。 